\title{
Dampak Cultural Invasion terhadap Kebudayaan Lokal: Studi Kasus Terhadap Bahasa Daerah
}

\author{
Gema Budiarto* \\ Departemen Sejarah, Fakultas IImu Budaya, Universitas Diponegoro \\ Jl. Prof. Soedarto, Tembalang Kota Semarang, Jawa Tengah 50275 \\ *Email: history.gema@gmail.com
}

Naskah diterima 24 Juli 2020, Revisi 13 September 2020, Terbit 29 Oktober 2020

\begin{abstract}
Abstrak
DOI: doi.org/10.21107/pamator.v13i2.8259

Kebudayaan merupakan aspek penting dari suatu peradaban manusia yang dapat menggambarkan aktifitas jalannya kehidupan manusia tersebut. Kehidupan manusia tidak akan lepas dari suatu kebudayaan, maka dapat dikatakan manusia adalah bagian inti dari kebudayaan. Adanya manusia dipastikan pula adanya suatu kebudayaan. Perkembangan kebudayaan berbeda dan memiliki ciri khas antara wilayah atau negara. Permasalahan yang diangkat dalam artikel ini adalah bagaimana dampak cultural invasion terhadap keberlangsungan suatu kebudayaan lokal terutama keberlangsungan bahasa daerah. Tujuan penelitian ini adalah mendeskripsikan dampak dari cultural invasion terhadap kebudayaan (bahasa) lokal, cultural invasion merupakan suatu ancaman bagi bahasa daerah jika pewaris kebudayaan tidak mampu menjaga jatidiri kebudayaannya. Metode penelitian yang digunakan dalam penelitian ini adalah metode kualitatif dengan teknik studi literatur dan observasi. Hasil penelitian ini menunjukkan bahwa cultural invasion memiliki dampak besar terhadap keberlangsungan bahasa daerah di suatu wilayah. Cultural invasion memanfaatkan komunikasi global sebagai upaya untuk menawarkan ide-idenya. Penyebar ide-ide tersebut memiliki klaim bahwa kebudayaannya lebih baik dibanding kebudayaan lain. Sehingga hal ini mampu mempengaruhi dan menekan kebudayaan lokal secara umum dan bahasa daerah secara khusus.
\end{abstract}

Kata Kunci: cultural invasion, kebudayaan lokal, bahasa daerah

\begin{abstract}
Culture is an essential aspect of the human civilization that can show life activities. The life of human cannot escape from a culture, therefore can be said the human is the core of culture. Human existence is a sign of culture existence cause human is the creator of culture. The cultural development in every single region or country will be different and have typical characteristics with each other. The formulation of the problem in this research is how the impact of cultural invasion on local culture, especially indigenous language. This article aims to discuss the impact of the cultural invasion on local culture (mother tongue), the cultural invasion is a threat to the mother tongue if the testator of the local culture cannot maintain his cultural identity. The research method is the qualitative method with the literature study and observation approach. The results showed that cultural invasion has a significant impact on mother tongue. Cultural invasion utilizing global communication as an effort to offering his ideas. The spreader of the ideas has the claim that his culture is better than another. So, it can affect and suppress the local culture in general and mother tongue in particular.
\end{abstract}

Keywords : cultural invasion, local culture, mother tongue

\section{PENDAHULUAN}

Manusia dan kebudayaan seperti dua sisi mata uang yang tidak dapat dipisahkan, adanya manusia pasti dipastikan ada pula suatu kebudayaan di wilayah yang dihuni oleh manusia yang mendiami ruang tersebut. Kebudayaan dipengaruhi oleh cara pandang manusia terhadap ruang hidupnya dan sengaja diciptakan oleh manusia sendiri untuk memenuhi suatu tuntutan hidup, sehingga menurut J.J. Hoenigman kebudayaan merupakan suatu gagasan, aktivitas, dan artefak (Jaya, 2013). Sifat kebudayaan sendiri adalah regenerasi yakni suatu kebudayaan diturunkan dari generasi ke generasi agar kebudayaan tersebut tetap bertahan dan tidak musnah. 
Antar generasi diharuskan memiliki kesadaran akan ketahanan budaya, meskipun tidak menutup kemungkinan suatu kebudayaan akan tetap mengalami perubahan seiring perkembangan zaman. Maka dari itu dapat disimpulkan bahwa, kebudayaan adalah segala sesuatu yang dibuat oleh manusia berupa aktifitas, ide, dan kebendaan yang difungsi sebagai alat pemenuhan kebutuhan hidup entah itu bersifat jasmani atau pun rohani. Kebudayaan bersifat fleksibilitas artinya kebudayaan tercipta karena zeitgeist dan mengalami perubahan juga karena zeitgeist itu sendiri dan kebudayaan bersifat kontinuitas, yakni diturunkan dari generasi ke generasi (Hendro, 2018).

Globalisasi dan perkembangan teknologi telah membawa perubahan yang cukup signifikan dalam kehidupan manusia. Di sini dapat dilihat lahirnya kebudayaan baru atau biasa disebut dengan modern culture sebagai tandingan dari traditional culture. Modern culture lahir disuatu negara tertentu tetapi bersifat transnasional dan penganut aliran modern culture sebagian besar adalah kalangan muda yang melek akan teknologi. Perbedaan yang signifikan juga terdapat dalam unsur yang terkandung dalam kebudayaan tradisional dan modern. Kebudayaan tradisional tumbuh dan berkembang dalam suatu lokalitas yang didukung oleh komunitas masyarakat yang terikat pada suatu aturan adat yang disepakati bersama, dan kebudayaan tradisional juga mengharuskan pemilik kebudayaan tersebut mewariskan secara turun-temurun, sedangkan kebudayaan modern yang cenderung berubah-ubah dengan mengadopsi unsur-unsur luar (Fauzan \& Nashar, 2017).

Sejatinya setiap kebudayaan yang bersifat tradisional atau modern sama-sama menghasil suatu produk-produk tertentu dan produk inilah yang nantinya akan diperkenalkan dan disebarkan ke penjuru dunia (Larasati, 2018). Gerak globalisasi dan perkembangan teknologi membawa kebudayaan-kebudayaan tradisional dan modern di suatu daerah dapat dikenal oleh masyarakat di belahan dunia lain. Pemilik kebudayaan dapat mengenalkan dan menyebarkan kebudayaannya melalui berbagai macam kecanggihan teknologi, pengenalan dan penyebaran tersebut dapat dikatakan sukses jika kebudayaan tersebut dapat diterima oleh manusia dalam kebudayaan lain tanpa adanya suatu pertentangan. Di sisi lain pengenalan dan penyebaran kebudayaan tersebut memiliki tujuan untuk melakukan cultural invasion. Tindakan tersebut tergolong invasi lunak yang tidak melibatkan kekutan militer dan dilakukan step by step. Cultural invasion sendiri adalah aktifitas yang dapat dikatakan kasat mata, jika manusia dalam kebudayaan lain tidak memiliki kesadaran budaya yang hakikatnya sebagai jati dirinya, maka kebudayaan luar (asing) yang masuk dapat menggerus dan melenyapkan kebudayaan lokal.

Cultural invasion memiliki konsekuensi yang merugikan dan mengakibatkan gangguan pada masyarakat. Cultural invasion harus ditangani secara serius sebab efek dari kebudayaan penyerbu (asing) dapat membanjiri dan menghancurkan integritas budaya penerima sehingga mengancam kenaturalan budaya kelompok-kelompok pribumi. Proses cultural invasion cenderung memiliki efek yang merugikan pada keanekaragaman budaya. Cultural invasion secara khusus menyerang negara-negara berkembang, namun, di mana pun cultural invasion terjadi akan tetap mengancam warisan kebudayaan lokal (The Encyclopedia of World Problems \& Human Potential, 2019). Panahi (2015) menegaskan bahwa "cultural invasion is a carefully planned and stealthy strategy that applies all resources to spoil the beliefs, change the values, distract thoughts, manipulate traditions, and destroying moral principles in a society".

Salah satu unsur kebudayaan yang paling terkena imbas dari cultural invasion yakni bahasa daerah. Menurut beberapa sumber mengatakan bahwa bahasa-bahasa daerah yang ada di Indonesia berstatus krisis, mengalami kemunduruan, dan ada yang stabil tetapi terancam punah (Ramadhan, 2017). Pendapat dari peneliti juga melaporkan bahwa bahasa-bahasa daerah di Indonesia rawan akan kepunahan. Laporan penelitian tersebut bukan hal yang mengejutkan bagi masyarakat, faktanya memperlihatkan bahwa penutur bahasa daerah semakin berkurang terutama pada generasi muda (Asrif, 2018). Bahasa ibu (mother tongue) merupakan warisan 
nusantara, apabila tidak dijaga dan dipelihara bahasa ibu tersebut akan tergerus oleh perkembangan zaman (Firdaus \& Setiadi, 2015). Tidak memungkiri bahwa bahasa Indonesia merupakan bahasa nasional atau sebagai bahasa persatuan yang menghubungkan latar belakang budaya yang berbeda di Indonesia. Namun, di sisi lain pelestarian bahasa ibu di masingmasing daerah perlu ditingkatkan dan dikembangkan.

\section{METODOLOGI}

Metode penelitian yang digunakan adalah kualitatif. Metode penelitian kualitatif merupakan metode penelitian yang bertujuan untuk melakukan pengamatan terhadap suatu fenomena sosial. Ada beberapa istilah lain yang digunakan dalam menyebut penelitian kualitatif, seperti penelitian atau inkuiri naturalistik atau alamiah, etnografi, interaksionis simbolik, etnometodologi, fenomenologis, studi kasus, interpretatif, ekologis, dan deskriptif. Metode penelitian ini merupakan sebuah penelitian yang menghasilkan data deskriptif berupa uraian kata-kata yang tertulis dari orang atau suatu fenomena yang diamati. Ditegaskan bahwa penelitian kualitatif menggunakan latar ilmiah, yang bermaksud untuk menafsirkan fenomena yang terjadi (Moleong, 2014).

Metode yang digunakan dalam penelitian ini adalah studi kasus. Studi kasus merupakan suatu strategi untuk mengungkap suatu kasus tertentu. Dalam studi kasus memusatkan perhatian pada satu object tertentu yang diangkat sebagai sebuah kasus (case) untuk dilakukan pengujian secara mendalam (Rahardjo, 2010). Kasus yang diangkat dalam penelitian ini memusatkan pada dampak cultural invasion terhadap kebudayaan lokal pada umumnya dan secara spesifik dampak terhadap keberlangsungan bahasa lokal atau daerah di Indonesia.

Teknik pengumpulan data dalam penelitian ini melalui studi literatur dan observasi tidak terstruktur. Teknik studi literatur dilakukan melalui pencarian datadata atau informasi melalui dokumen, baik dokumen cetak maupun elektronik yang memiliki kaitan dengan cultural invasion. Sedangkan observasi tidak terstruktur dilakukan dengan mencatat hasil pengamatan yang didapat.

\section{HASIL PEMBAHASAN Persaingan antar Kebudayaan}

Kebudayaan merupakan warisan dari leluhur umat manusia dengan ciri khasnya masing-masing dan melalui simbol-simbol khusus yang memiliki pemaknaan yang berbeda-beda pula. Manusia adalah mahkluk zoon politicon artinya hewan yang hidup bermasyarakat, maka kebudayaan dapat diteruskan secara garis mendatar yakni kepada orang-orang di sekitar, jadi tidak hanya diteruskan secara tegak lurus (keturunan darah) (Soekmono, 1973).

Proses regenerasi merupakan suatu keharusan bagi pewaris kebudayaan untuk mempertahankan eksistensi kebudayaannya tetapi seiring perkembangan zaman menuntut adanya perubahan dalam kebudayaan. Kebudayaan mengalami suatu perkembangan dinamis, perkembangan tersebut seiring dengan perkembangan pencipta kebudayaan yakni manusia, oleh sebab itu tidak ada kebudayaan yang bersifat statis atau tidak menyesuaikan dengan zaman (Setiadi et.al, 2006).

Aktivitas yang paling terlihat saat ini adalah cara hidup, yakni proses pergeseran dari aktivitas hidup tradisional menuju modern dengan memanfaatkan hasil teknologi buatan manusia sehingga memudahkan aktivitas dalam kehidupannya. Tidak jarang proses pergeseran tersebut memiliki anggapan bahwa sesuatu yang kuno atau tradisional merupakan hal-hal yang tidak penting. Sehingga di sini menimbulkan pertanyaan tantangan bagi manusia, apakah dia ingin di tempat atau maju. Tetap berada di tempat berarti kuno tetapi jika berani maju ke depan akan menjadi manusia yang modern (Liliweri, 2002).

Proses pergeseran cara hidup dari tradisional menuju modern memang diperlukan dan tidak dapat dihindari sesuai apa yang dijelaskan dalam teori modernisasi, tetapi jika proses pergeseran tersebut menyangkut tradisi lokal atau tradisi-tradisi yang memiliki nilai sakral hal itu akan membawa dampak buruk bagi jati diri sang pewaris kebudayaan, apalagi jika menggunakan anggapan "yang kuno merupakan hal yang tidak penting" ini akan 
menghilangkan kearifan lokal sehingga jati diri manusia pewaris kebudayaan juga akan akan hilang. Perkembangan memang suatu tuntutan meskipun begitu tidak harus menghilangkan ciri khas dan jati diri pewaris kebudayaan. Sehingga mempertahankan kebudayaan lokal memang harus menjadi prioritas dan kesadaran bersama bagi pewaris kebudayaan.

Proses dasar pelestarian kebudayaan lokal dapat melalui dua cara yakni culture experience dan culture knowledge. Culture experience merupakan cara pelestarian kebudayaan yang dilakukan dengan terjun langsung untuk mengenali, mendalami, dan membiasakan diri terhadap kebudayaan tersebut sebagai suatu pengalaman kultural. Culture knowledge merupakan cara pelestarian kebudayaan yang dilakukan dengan cara membuat suatu culture information center yang ditujukan untuk edukasi atau pengembangan kebudayaan itu sendiri (Nahak, 2019).

Proses pelestarian kebudayaan di era global dapat ditempuh dengan cara penyesuaian, yakni melalui proses memilah suatu kebudayaan luar yang masuk. Tidak semua unsur-unsur kebudayaan luar sesuai dengan cara pandang pewaris kebudayaan lain di suatu daerah, sehingga diperlukan kontrol dalam masyarakat sebagai pengendali masuknya unsur-unsur luar. Selain itu proses pelestarian kebudayaan dapat ditempuh melalui pengenalan kebudayaan ke masyarakat dengan kebudayaan lain. Diterima dalam masyarakat kebudayaan lain merupakan tujuan dari proses ini, sehingga muncullah ketertarikan dalam masyarakat kebudayaan lain untuk tergugah mendalaminya. Hal positif dalam proses pendalaman ini akan menambah wawasan kebudayaan, tetapi hal negatifnya yakni hilangnya kebudayaan lokal dan digantikan kebudayaan asing yang masuk jika masyarakatnya pewaris kebudayaan tidak memiliki kesadaran budaya. Ini juga merupakan bagian penting dari persaingan kebudayaan.

Sisi lain dari proses pengenalan tersebut yakni adanya aktivitas persaingan antar budaya yang memiliki anggapan bahwa kebudayaannya yang paling unggul. Terjadinya suatu persaingan atau kompetisi ini menciptakan suatu perlombaan antar kebudayaan dengan tujuan untuk saling mengungguli, yang menjadi penilai dan sasaran adalah masyarakat dari kebudayaan lain. Persaingan ini sendiri merupakan bagian proses sosial disosiatif atau dikenal sebagai Oppositional processes, yakni proses sosial yang mengarah pada suatu kecenderungan untuk melakukan perlawanan demi terwujudnya tujuan tertentu sebagai perjuangan agar tetap hidup (struggle for existence) (Narwoko \& Suyanto, 2011). Persaingan ini menyangkut dalam berbagai bidang seperti: agama, perekonomian, dan termasuk bahasa.

Proses kompetisi menimbulkan attack and defense. Konsep attack and defense ini digunakan oleh masing-masing pendukung kebudayaan. Attack memiliki pengertian masyarakat pewaris menggunakan kemampuannya untuk membumikan kebudayaannya melalui berbagai cara. Cara kuno yang dipakai adalah melalui invasi peperangan, daerah yang diduduki diwajibkan untuk mengikuti kebudayaan negara penjajah, sedangkan saat ini menggunakan cara lunak (non-militer) yang dipakai adalah melalui pemanfaatan perkembangan teknologi komunikasi sehingga jangkauannnya lebih luas, menyeluruh dan memanfaatkan kelemahan kesadaran budaya lokal dalam masyarakat kebudayaan lain. Sedangkan untuk defense seperti apa yang telah dijelaskan di atas yakni adanya filter terhadap kebudayaan asing yang masuk. Konsep defense tergantung dari masyarakat dalam kebudayaan lain, bagaimana masyarakat tersebut memandang kebudayaan asing itu, apakah menerima atau menolaknya.

\section{Penyebaran Kebudayaan dalam Masyarakat Global}

Pertemuan antar kebudayaan merupakan proses dari penyebaran itu sendiri, proses ini dapat melalui beberapa cara, antara lain: symbiotic relations, penetration violante, dan penetration pacifique (Jatmiko, 2015). Cara pertama symbiotic relations pertemuan antar pemilik kebudayaan satu dengan yang lainnya tanpa mengubah unsur-unsur kebudayaan dari kedua belah pihak. Cara kedua, penetration violante atau imperialisme kebudayaan yakni proses penyebaran kebudayaan yang dilakukan dengan jalan kekerasan, dalam hal ini dapat 
diartikan adalah invasi militer ke wilayah lain. Pendudukan ini merupakan tahap awal masuknya kebudayaan negara penjajah ke wilayah jajahan. Wilayah yang ditahklukkan dianggap sebagai wilayah rendahan sehingga harus patuh terhadap aturanaturan yang dibuat oleh pihak penjajah. Cara ketiga, penetration pacifique yakni proses penyebaran suatu kebudayaan yang dilakukan secara damai tanpa paksaan. Tujuan dasar dari penyebaran kebudayaan untuk mengenalkan kebudayaannya keseluruh penjuru masyarakat global. Kebudayaan merupakan hasil cipta manusia, maka dapat diartikan penyebaran tersebut juga memiliki tujuan untuk menawarkan hasil ciptanya kepada masyarakat lain agar dapat digunakan. Jika suatu kebudayaan dipakai oleh masyarakat dalam kebudayaan lain, hal itu merupakan suatu kebanggaan bagi pemilik kebudayaan yang dipakai.

Seiring berkembangnya zaman, proses penyebaran kebudayaan juga masih tetap gencar dilakukan oleh masyarakat di seluruh penjuru dunia. Pemanfaatan perkembangan teknologi informasi dan komunikasi semakin mudahnya penyebaran tersebut dapat dilakukan oleh siapapun, kapanpun, dan dimanapun, jadi globalisasi memiliki peranan penting dalam hal ini. Mestika Zed dalam Isputaminingsih (2014) memaparkan bahwa ada tiga paradigma globalisasi. Pertama, Clash of Civilization, yakni globalisasi hadir dalam suatu bentuk "benturan peradaban", persaingan antara satu dengan yang lainnya. Kedua, McDonaldization, yakni globalisasi merupakan "global economy" yang ditandai lahirnya kapitalisme yang didukung dengan perkembangan teknologi dan informasi. Ketiga, Hybridization: the rhizome of culture, yakni globalisasi merupakan suatu bentuk budaya itu sendiri.

Globalisasi merupakan suatu arena bagi para pemilik kebudayaan untuk bersaing dalam menyebarkan kebudayaannya. Globalisasi juga akan menentukan suatu kebudayaan apakah kebudayaan tersebut dapat bertahan dari persaingan global atau akan hilang digerus oleh kebudayaan lain yang lebih kuat. Kuat atau lemahnya kebudayaan ditentukan dari masyarakat dalam kebudayaan itu sendiri, bagaimana masyarakat tersebut akan mempertahankan atau melestarikan.
Banyak berpendapat bahwa globalisasi merupakan suatu produk yang baru lahir, tetapi globalisasi itu sendiri telah ada sejak dahulu sebelum kecanggihan teknologi komunikasi dan informasi berupa internet lahir. Degradasi kebudayaan secara umum dan bahasa pada khususnya terjadi karena pengaruh luar yang merupakan dampak dari globalisasi. Menurut data yang disajikan oleh Summer Linguistic, Indonesia memiliki bahasa daerah sebanyak 746 bahasa, tetapi dari sekian banyak bahasa yang dimiliki sebanyak 25 bahasa daerah terancam punah dan sebanyak 13 bahasa daerah telah dinyatakan punah (Haryanto, 2016).

Hal semacam ini tidak boleh diremehkan, sebab jika pewaris kebudayaan tidak mempertahankan dan melestarikan, tidak menutup kemungkinan akan berdampak dan menggerus pada bahasa daerah lainnya. Alwi Rahman mengatakan bahwa bahasa tidak dapat digantikan dengan bahasa lain, bahasa daerah bukan hanya sebagai alat komunikasi tetapi di dalam bahasa daerah terkandung nuansa alam pikir masyarakat Hal senada juga dijelaskan oleh Gubernur Bali Wayan Koster, ada suatu keterkaitan antara Bahasa Bali dengan identitas masyarakat atau manusia Bali. Bahasa Bali merupakan suatu pengikat kebudayaan dan masyarakat Bali. Selain itu Bahasa Bali juga merupakan jati diri serta identitas masyarakat Bali (Balipost, 2020).

Dalam interaksi global masing-masing kebudayaan memiliki dua indikator yang harus dijalankan pertama adalah berusaha untuk mempertahankan kebudayaannya dari penetrasi kebudayaan lain dan kedua yakni berusaha untuk mempenetrasikan kebudayaannya kepada bangsa lain. Sejak dari dahulu, dalam faktanya globalisasi dikuasai oleh pihak-pihak yang memiliki kekuatan finansial yang tinggi dan menghegemoni bangsa yang memiliki finansial rendah, sehingga kebudayaan lokal pun juga akan ikut terpengaruh karena adanya monopoli dari pihak asing (Yuniarto, 2011). Globalisasi akan menjadi ancaman serius bagi identitas lokal bangsa, jika ketahanan budaya bangsa tersebut lemah, globalisasi yang menimbulkan suatu homogenisasi dapat melemahkan nilai kultur masyarakat yang mempengaruhi segala aspek kehidupan terutama gaya hidup. 
Gerak globalisasi akan membawa pengaruh-pengaruh asing ke suatu negara sehingga dapat menimbulkan degradasi kebudayaan jika negara tersebut lemah dalam memfilter pengaruh-pengaruh yang masuk (Budiarto, 2020). Meskipun gerak globalisasi tidak bisa dihentikan tetapi dampak-dampaknya yang sekiranya merugikan masih bisa diminimalisir dan semua ini tergantung dari sang pewaris kebudayaan itu sendiri (Mubah, 2011).

UNESCO (United Nations Educational, Science and Cultural Organization) dalam Declaration of Principles of International Cultural Co-operation telah menegaskan dalam Pasal I, Point pertama yakni "Each culture has a dignity and value which must be respected and preserved' dan Point kedua yakni "Every people has the right and the duty to develop its culture" (UNESCO, 1966). Adanya ketentuan tersebut menegaskan bahwa kebudayaan memang harus dijaga dan dilestarikan.

\section{Dampak Cultural Invasion terhadap Bahasa Daerah}

Globalisasi berdampak pada terjadinya cultural invasion yang bertanggung jawab atas hilangnya suatu kebudayaan yang dianggap lemah atau kebudayaan yang tidak mampu untuk bersaing (berkompetisi) dengan kebudayaan lainnya. Pada era global, sebagian orang mungkin tidak menyadari akan adanya cultural invasion tersebut dan dianggap sebagai hal yang biasa saja, alih-alih untuk memperkenalkan suatu kebudayaan tetapi berdampak pada proses penetrasi yang sedikit demi sedikit akan melemahkan kebudayaan lokal. Proses ini tidak bisa dilawan secara fisik, tetapi sadar atau tidak proses ini telah menjadi semacam kesepakatan bersama antar warga global.

Proses cultural invasion lebih menargetkan pada generasi muda yang jenuh akan kebudayaan lokalnya, memanjakannya dengan suatu kebudayaan asing. Arus globalisasi memang merupakan pemicu terjadinya guncangan kebudayaan lokal terlebih lagi terhadap bahasa daerah, tetapi kita juga harus sadar terhadap diri sendiri bahwa ketahanan budaya hanya pewaris kebudayaannya sajalah yang bisa melakukannya dan ini juga patut untuk diperhatikan. Kesadaran dari pewaris kebudayaan lokal harus dikuatkan karena itu merupakan kunci dalam pelestarian kebudayaan, sebaliknya jika kesadaran itu melemah maka akan memudahkan proses cultural invasion untuk masuk. Sesungguhnya gerak nyata yang menimbulkan berubahan adalah kebudayaan yang berasal dari luar, tumbangnya suatu kebudayaan karena kebudayaan lain jika kebudayaan tersebut dipaksakan kepada masyarakat lain (Soekmono, 1973).

Cultural invasion merupakan tantangan tersendiri bagi pelestarian bahasa daerah, seiring dengan perubahan hidup yang lebih modern menuntut pula kemodernan dalam suatu kebudayaan. Masyarakat akan memilih sesuatu yang baru yang sekiranya sesuai dengan zamannya dia hidup saat itu. Negara-negara yang memiliki tujuan cultural invasion lebih giat dalam menyebarkannya kebudayaannya ke seluruh dunia. Secara garis besar, globalisasi telah menghilangkan batas-batas wilayah suatu negara dan cenderung menafikan perbedaan budaya lalu ingin bersama untuk memandang dunia hanya dalam satu budaya, yakni budaya global (Liliweri, 2002), hal sedemikian rupa juga diadopsi dalam cultural invasion.

Cultural invasion menghendaki adanya satu kebudayaan dalam satu dunia sehingga proses penetrasi yang dilakukan oleh negara maju ke berbagai negara terutama negara berkembang akan terus digencarkan. Menuntut adanya suatu kesamaan dalam satu kehidupan, kecenderungan adanya homogenisasi yang akan menghilangkan kekhasan atau keunikan identitas kebudayaan lokalnya. Cultural invasion menghapus segala perbedaan dan sengaja menciptakan suatu pola kehidupan yang sama (Ana Cristina Gil, dalam Mubah, 2011).

Dampak yang dapat kita rasakan saat ini dari cultural invasion yakni degradasi bahasa daerah. Dalam UUD 1945, Bab XIII, Pasal 32, Ayat (2) dinyatakan bahwa Negara menghormati dan memelihara bahasa daerah sebagai kekayaan budaya nasional. Lalu, dalam penjelasan Pasal 36 Bab XV Undang-Undang Dasar 1945, bahasabahasa daerah yang dipakai di wilayah Indonesia perlu dipelihara dan dikembangkan. Usaha dalam pembinaan dan pengembangan tersebut melalui 
kegiatan inventarisasi dan peningkatan mutu pemakaian (Pusat Pembinaan dan Pengembangan Bahasa, 1975: 7). Dari penjelasan tersebut dapat disimpulkan bahwa bahasa daerah memiliki kedudukan yang esensial. Oleh sebab itu, Sebagai generasi penerus memang memiliki kewajiban untuk menjaga dan melestarikan bahasa daerah tetapi faktanya tekanan culture invasion sepertinya lebih kuat. Proses cultural invasion dilakukan secara damai melalui media teknologi informasi dan komunikasi yang dapat kita lihat saat ini juga dan membawa pengaruh yang sangat besar dalam kehidupan. Banyaknya produkproduk budaya asing yang masuk, hal ini menandakan terjadinya suatu perkembangan inovatif manusia, tetapi dilain pihak secara tidak sadar pergeseran kebudayaan (bahasa daerah) juga terjadi dan dapat ditandai dengan hilangnya nilainilai kebudayaan lokal secara perlahan.

Komunikasi yang telah terhubung secara global melalui berbagai media elektronik memberikan sumbangan besar bagi perubahan suatu kebudayaan. Menurut Naisbitt dan Alfin Toffler dalam Hernawan (2012) memberikan istilah untuk masyarakat global saat ini adalah information society yakni kelompok masyarakat yang memiliki ciri khas peradaban dengan memanfaatkan penggunaan elektronik, komputer, robot, dan kecanggihan-kecanggihan lainnya. Media-media teknologi, informasi dan komunikasi tersebut membawa berbagai macam pesan-pesan yang dapat mempengaruhi suatu kebudayaan lain. Ada tiga point penting bahwa media dapat mempengaruhi kebudayaan. Pertama, media berperan sebagai kekuatan yang dapat memperkokoh dan membimbing masyarakat bahwa kebudayaannya masih tetap berlaku dan dipatuhi. Kedua, media dapat menciptakan pola baru dalam kebudayaan lain, hal ini berarti tidak adanya pertentangan dengan kebudayaan yang telah ada. Ketiga, media dapat menghilangkan kebudayaan yang telah ada sebelumnya dan menggantikan dengan suatu kebudayaan baru. Point yang ketiga inilah yang harus menjadi perhatian utama, karena media di sini dijadikan kendaraan oleh pihak lain sebagai alat untuk melakukan cultural invasion untuk menghilangkan kebudayaan lokal. Hilangnya kebudayaan suatu daerah berarti hilangnya juga identitas dan jati diri suatu peradaban manusia.

Globalisasi mengandung beberapa indikator yang telah dijelaskan oleh Jan Aart Scholte dalam Mubah (2011), antara lain: (1) internasionalisasi, (2) liberalisasi ekonomi, (3) westernisasi, (4) demokratisasi, dan (5) deteritorialisasi. Westernisasi merupakan masuknya nilai-nilai kebudayaan Barat (Eropa dan Amerika) ke suatu negara. Westernisasi dianggap sebagai kebudayaan yang paling maju oleh beberapa pihak dan mengeyampingkan kebudayaan lokal. Sedangkan untuk deteritorialisasi adalah memudarnya peran negara dalam memfilter segala unsur dari luar yang masuk kenegaranya, sehingga masing-masing individu bebas untuk melakukan interaksi dengan kebudayaan lain dan individu juga bebas untuk mendapat atau memakai suatu kebudayaan lain pula, sehingga muncullah proses adopsi, artinya masyarakat melakukan adopsi kebudayaan yang telah dikembangkan oleh bangsa lain di tempat lain (Setiadi et.al, 2006).

Bermacam-macam kebudayaan luar masuk dengan membawa berbagai macam aspek, seperti filsafat, ideologi, ilmu pengetahuan, dan bahasa. Dalam segi bahasa, jika ada dua bahasa yang saling bersanding pemakaiannya, maka akan terjadi dua kemungkinan. Pertama, kedua bahasa tersebut akan berdampingan secara berkesinambungan dalam kesetaraan. Kedua, salah satu bahasa akan lebih dominan dan yang lain akan hilang bahkan akan punah. Sejatinya "bahasa memiliki keterkaitan erat dengan budaya", jadi keduanya tidak dapat dipisahkan (Yati, 2015).

Menurut Marshall McLuhan dalam Mubah (2011) saat ini dunia mengalami 4T (Technology, Telecomunication, Transportation, Tourism) yang mencintakan global village. Kondisi ini dapat memunculkan berbagai permasalahan seperti melunturnya nilai-nilai identitas suatu peradaban lokal salah satunya yakni bahasa. Bukti kuat yang telah ada yakni life style dalam masyarakat, mulai dari cara berpakaian, pola-pola konsumtif (hedonism), dan penggunaan bahasa-bahasa yang tren. Penggunaan bahasa-bahasa asing dianggap dan dipandang lebih bernilai, lebih 
maju, dan lebih modern. Penggunaan bahasa asing tersebut juga dipengaruhi oleh komunitas dimana orang tersebut bergaul. Mereka memandang bahwa segalanya yang dari luar adalah sesuatu yang modern dan memandang peradaban sendiri sebagai peradaban yang kuno.

Cultural invasion tersebut merupakan suatu tekanan kebudayaan asing terhadap kebudayaan lokal khususnya bahasa daerah, hal ini sejalan dengan apa yang dinyatakan oleh Wales sebagai akulturasi ekstreme yang mengakibatkan hilangnya unsur-unsur peradaban lokal atau local genius. Kardiner menyebutkan istilah local genius tersebut sebagai basic personality yang dimiliki oleh masing-masing kebudayaan (Mustopo, 2003). Dengan kata lain, cultural invasion tersebut bertujuan untuk menghilangkan unsur ciri-ciri budaya yang khas, yang dimiliki oleh masyarakat secara bersama sebagai hasil dari masa lalunya dengan kebudayaan yang baru. Oleh karena itu, para pewaris kebudayaan perlu mengembangkan, menjaga, dan mempertahankan local wisdom, sebab nilainilai budaya lokal merupakan jati diri dan jiwa yang dimiliki oleh sang pewaris kebudayaan (Ufie, 2014). Bahasa daerah memiliki fungsai penting sebagai penanda kelompok-kelompok sosial yang berbeda, jika suatu bahasa punah maka akan lebih sulit untuk memulihkannya dari pada penanda identitas lainnya (UNESCO, 2011).

Pewaris kebudayaan harus memiliki sikap untuk peduli dalam melestarikan kebudayaan lokal. Cultural invasion akan selalu memberikan ancaman terhadap kebudayaan, local genius tersebut tidak akan hilang jika pewaris kebudayaan dapat memanfaatkannya sebagai filter terhadap kebudayaan asing yang masuk. Local genius akan selalu menampilkan diri sebagai agen dalam memilih, mengambil unsur dari budaya asing yang diperlukan saja, sehingga local genius memungkinkan kebudayaan asing tidak sampai menghilangkan aspek kebudayaan yang telah ada sebelumnya.

Local genius disini mencakup seluruh hasil kebudayaan yang dihasilkan oleh suatu peradaban masyarakat tertentu. Dapat ditarik kesimpulkan bahwa jika kesadaran budaya pewaris kebudayaan kuat maka local genius pun juga akan kuat, sehingga culture heritage akan tetap terjaga untuk selamanya.

\section{KESIMPULAN}

Kebudayaan merupakan warisan leluhur suatu peradaban masyarakat dengan ciri khas yang berbeda-beda antar satu dengan yang lainnya. Seiring berkembangnya zaman, maka menuntut pula perkembangan kebudayaan ke arah yang lebih baik secara IPTEK. Tetapi dilain pihak, arus globalisasi melahirkan cultural invasion yang memiliki tujuan untuk mempenetrasikan suatu kebudayaan ke dalam kebudayaan lain yang dianggap lebih lemah. Maka, globalisasi juga akan menentukan suatu kebudayaan apakah kebudayaan tersebut dapat bertahan dari persaingan global atau akan hilang digerus oleh kebudayaan lain yang lebih kuat.

Cultural invasion lebih menargetkan pada generasi muda yang jenuh akan kebudayaan lokalnya, memanjakannya dengan suatu kebudayaan baru. Menuntut adanya suatu kesamaan dalam satu kehidupan, kecenderungan adanya homogenisasi yang akan menghilangkan kekhasan atau keunikan identitas kebudayaan lokal. Perlu diperhatikan, bahwa cultural invasion tidak hanya terjadi pada saat ini, tetapi proses tersebut telah ada sejak dahulu, sejak manusia belum memanfaatkan kecanggihan teknologi. Bahasa daerah merupakan salah satu unsur kebudayaan yang terancam atas cultural invasion tersebut.

Seiring berkembangnya zaman, bahasa daerah dibeberapa wilayah di Indonesia berstatus kritis, mengalami kemunduran hingga terancam punah. Pada dasarnya Indonesia memiliki ratusan bahasa daerah, meskipun jumlahnya sangat banyak tidak menutup kemungkinan bahasa-bahasa daerah tersebut sedikit demi sedikit akan punah jika pewaris kebudayaan tidak melestarikannya secara sadar. Menurut UNESCO bahasa dapat dikatakan "aman" jika bahasa tersebut dituturkan dari generasi ke generasi (antar generasi yang tidak terputus). Di sisi lain, peran pemerintah juga sangat penting untuk menaungi lembagalembaga pengembangan dan pelestarian bahasa daerah. 


\section{DAFTAR PUSTAKA}

Alamati, G. 2016. Define the Relation between War and Cultural Invasion and Target Groups. Journal Politics and Law. Vol 9 (5). 209-213 pp.

Asrif. 2018. Bahasa Daerah, Erosi Identitas, dan Peran Orang Tua. https://kantorbahasamaluku.kemdikbud.g o.id/2018/07/bahasa-daerah-erosiidentitas-dan-peran-orang-tua-2/. Diakses pada 16 Juli 2020.

Balipost. 2020. Bahasa Bali Terdegradasi, Identitas Manusia Bali Terancam. https://www.balipost.com/news/2020/02/0 3/102249/Bahasa-Bali-

Terdegradasi, Identitas-ManusiaBali...html. Diakses pada 19 Juli 2020.

Budiarto, G. 2020. Indonesia dalam Pusaran Globalisasi dan Pengaruhnya Terhadap Krisis Moral dan Karakter. Jurnal Pamator. Vol 13 (1). 50-56 pp.

Ekwandari, Y.S., Perdana, Y \& Lestari, N.I. 2020. Integrasi Pendidikan Multikultural dalam Pembelajaran Sejarah di SMA YP UNILA. Jurnal Criksetra. Vol 9 (1). 15-31 pp.

Fauzan, R., \& Nashar. 2017. Mempertahankan Tradisi, Melestarikan Budaya (Kajian Historis dan Nilai Budaya Lokal Kesenian Terebang Gede di Kota Serang). Jurnal Candrasangkala. Vol 3 (1). 1-9 pp.

Firdaus, A., \& Setiadi, D. 2015. Pelestarian Bahasa Daerah (Sunda) Dalam Upaya Mengokohkan Kebudayaan Nasional. Dalam: Seminar Nasional : Pertemuan IImiah Bahasa Sastra Indonesia (PIBSI) XXXVII, 2-3 Oktober 2015, Yogyakarta.

Gazalba, S. 1974. Antropologi Budaya. Jakarta: Bulan Bintang.

Haviland, W.A. 1985. Antropologi, Jilid 1. Jakarta: Erlangga.

Haryanto, A. 2016. Bahasa-Bahasa Daerah yang Hampir Punah. https://tirto.id/bahasa-bahasa-daerahyang-hampir-musnah-bu9C. Diakses pada 18 Juli 2020.

Hendro, E.P. 2018. Membangun Masyarakat Berkepribadian di Bidang Kebudayaan dalam Memperkuat Jawa Tengah sebagai Pusat Kebudayaan Jawa. Endogami. Jurnal Ilmiah Kajian Antropologi. Vol 1 (2). 149-165 pp.

Hernawan, W. 2012. Pengaruh Media Massa Terhadap Perubahan Sosial Budaya dan Modernisasi dalam Pembangunan. Kom dan Realitas Sosial. Jurnal IImu Komunikasi Universitas Bandar Lampung. Vol 4 (4). 83-96 pp.

Isputaminingsih. 2014. Membangun Budaya Harmonis dan Religius di Era Global. Jurnal Criksetra. Vol 3 (2). 73-85 pp.

Jatmiko, E.M. 2015. Struktur Bentuk Komposisi dan Akulturasi Musik Terbang Biola Sabdo Rahayu Desa Pekiringan, Kecamatan Talang, Kabupaten Tegal. Catharsis: Journal of Arts Education. Vol 4 (1). 4-14 pp.

Jaya, M.T.B.S. 2013. Community and Cultural Environment (Analysis on Environmental Education Culture of Lampung). Southeast Asian Journal of Social and Political Issues. Vol 1 (3). 235$246 \mathrm{pp}$.

Larasati, D. 2018. Globalisasi Budaya dan Identitas: Pengaruh dan Eksistensi Hallyu (Korean Wave) versus Westernisasi di Indonesia. Jurnal Hubungan Internasional. Vol 11 (1). 109-120 pp.

Liliweri, A. 2002. Makna Budaya dalam Komunikasi Antarbudaya. Yogyakarta: LKis.

Listyani, B., Sunardi., \& Wuryani, E. (2020). Membangun Karakter dan Budi Pekerti Petani Melalui Tradisi Wiwitan di Desa Gilangharjo Pandak Bantul. Jurnal Criksetra. Vol 9 (1). 59-71 pp.

Moleong, L.J. 2014. Metodologi Penelitian Kualitatif. Bandung: Rosdakarya.

Mubah, A.S. 2011. Revitalisasi Identitas Kultural Indonesia di Tengah Upaya Homogenisasi Global. Global \& Strategis. Edisi Khusus. 251-260 pp. . (2011). Strategi Meningkatkan Daya Tahan Budaya Lokal dalam Menghadapi Arus Globalisasi. Jurnal Masyarakat Kebudayaan, dan Politik. Vol 24 (4). 302308 pp. 
Mustopo, M.H. 2003. Local Genius dalam Konteks Perubahan Budaya di Asia Tenggara. Dalam "Sejarah dan Budaya dari Masa Kuno sampai Kontemporer". Malang: UM Press.

Nahak, H.M.I. 2019. Upaya Melestarikan Budaya Indonesia di Era Globalisasi. Jurnal Sosiologi Nusantara. Vol 5 (1). 65$76 \mathrm{pp}$.

Narwoko, J.D., \& Suyanto, B. 2011. Sosiologi Teks Pengantar dan Terapan. Jakarta: Kencana.

Oktavianus. 2013. Bahasa yang Membentuk Jati Diri dan Karakter Bangsa. Jurnal Arbitrer. Vol 1 (1). 68-74 pp.

Panahi, A. 2015. Cultural Invasion And Moral Insecurity In Thoughts Of Imam Khamenei. Science Journal (CSJ). Vol 36 (3). 3449-3457 pp.

Prayogi, R., \& Danial, E. 2016. Pergeseran Nilai-Nilai Budaya pada Suku Bonai sebagai Civic Culture di Kecamatan Bonai Darussalam Kabupaten Rokan Hulu Provinsi Riau. Humanika. Vol 23 (1). 61-79 pp.

Pusat Pembinaan dan Pengembangan Bahasa. 1975. Hasil Perumusan Seminar Politik Bahasa National (Jakarta, 25-28 Februari 1975). Jakarta: Departement Pendidikan dan Kebudayaan.

Rahardjo, M. (2010). Mengenal Lebih Jauh Tentang Studi Kasus. https://www.uinmalang.ac.id/r/100501/mengenal-lebihjauh-tentang-studi-kasus.html. Diakses pada 17 Juli 2020.

Ramadhan, A. 2017. Kemendikbud Revitalisasi Bahasa Daerah Cegah Kepunahan.

https://www.antaranews.com/berita/6723

17/kemendikbud-revitalisasi-bahasadaerah-cegah-kepunahan. Diakses pada 16 Juli 2020.

Rusdianto, E. Tanpa Tahun. Bahasa Daerah yang Terancam Punah. https://historia.id/kultur/articles/bahasadaerah-yang-terancam-punah-P9jxZ. Diakses pada 18 Juli 2020.

Setiadi, E.M., et al. (2006). Ilmu Sosial dan Budaya Dasar. Jakarta: Kencana.
Setyaningrum, N.D.B. (2018). Budaya Lokal di Era Global. Jurnal Ekspresi Seni. 20 (2): 102-112.

Soekmono, R. (1973). Pengantar Sejarah Kebudayaan Indonesia 1. Yogyakarta: Kanisius.

Sztompka, P. (2007). Sosiologi Perubahan Sosial. Jakarta: Pernada Media Grup.

The Encyclopedia of World Problems \& Human Potential. (2019). Cultural Invasion.

http://encyclopedia.uia.org/en/problem/13 7314. Diakses pada 19 Juli 2020.

Tim Penyusun MKD UIN Sunan Ampel Surabaya. (2018). IImu Alamiah Dsaar, IImu Sosial Dasar, IImu Budaya Dasar (IAD-ISD-IBD). Surabaya: UIN Sunan Ampel Press.

Ufie, A. (2014). Mengintegrasikan Nilai-Nilai Multikulturalisme Berbasis Kearifan Lokal Sebagai Sumber Pembelajaran Sejarah. Jurnal Criksetra. 3 (2): 47-61.

UNESCO. (1966). Declaration of Principles of International Cultural Co-operation. http://portal.unesco.org/en/ev.phpURL ID=13147\&URL DO=DO TOPIC\& URL SECTION=201.html. Diakses pada 9 April 2020.

UNESCO. (2011). Berinvestasi dalam Keanekaragaman Budaya dan Dialog Antarbudaya (Dwi A. Indrasari, Trans). Organisasi Perserikatan Bangsa-Bangsa bidang Pendidikan, IImu Pengetahuan, dan Budaya.

Yati, D. (2015). Menyelamatkan Bahasa Daerah Melalui Pembelajaran Bahasa yang Komunikatif. Prosiding Seminar Nasional Bulan Bahasa 2015. Unit Penerbitan FKIP Universitas Bengkulu.

Yuniarto, P.R. (2011). Masalah Globalisasi di Indonesia: Antara Kepentingan, Kebijakan, dan Tantangan. Jurnal Kajian Wilayah, Lembaga IImu Pengetahuan Indonesia. 5 (1): 67-95.

Zhang, Y. (2018). Views on the Cultural Invasion. Advances in Social Science, Education and Humanities Research (ASSEHR). 199: 162-168. 
Arikunto, S. 2011. Prosedur Penelitian Suatu Pendekatan Praktek. Edisi Ketiga. pp.109

Prawatya \& Raharjo. 2012. Pengaruh Disiplin Kerja dan Budaya Organisasi Terhadap Kinerja Karyawan Pabrik Minyak Kayu Putih (PMKP) di Krai Purwodadi. Diponegoro Journal Of Management Volome 1 (1). 323-333 pp.

Prawirosentono, S. 2009. Perilaku Organisasi. Jakarta. Bumi Aksara.

Ridwan, 2010. Skala pengukuran VariabelVariabel Penelitian. Cetakan Ketiga, Alfabeta. Bandung.

Robbins S. P. 2014, Perilaku Organisasi : Konsep, Kontroversi, Aplikasi. Versi Bahasa Indonesia. Jilid 1 \& 2. PT Prenhallindo. Jakarta.

Robbins, 2010, Perilaku Organisasi Buku 1 dan 2. Jakarta : Salemba Empat
Robbins, P.S. \& T. A. Judge. 2012. Perilaku Organisasi. Jakarta : Salemba.

Raharjo, Paramita \& Warso. 2016. Pengaruh Kemampuan Kerja, Pengalaman dan Pelatihan Terhadap Produktivitas Kerja Karyawan Dengan Kompetensi Kerja Sebagai Variabel Intervening (studi kasus pada KUD "PATI KOTA" Kabupaten Pati). Journal Of Management. Vol.2 (2).

Sedarmayanti. 2009. Sumber Daya Manusia dan Produktivitas Kerja. Bandung : Penerbit Mandar Maju

Sugiyono, 2011. Metodologi Penelitian Kuantitatif dan Kualitatif, Bandung : CV Alfabeta. 